\title{
Potential use of recycled construction and demolition waste aggregates for non-structural concrete applications
}

\author{
S. Jayakody ${ }^{1 *}$, A.M.Z. Zimar ${ }^{1}$ and R.A.L.M. Ranaweera ${ }^{2}$ \\ ${ }^{I}$ Faculty of Engineering, South Eastern University of Sri Lanka, P.O. Box 1, University Park, Oluvil. \\ ${ }^{2}$ The Institution of Engineers, Sri Lanka, 120/15, Wijerama Mawatha, Colombo 07.
}

Revised: 24 January 2018; Accepted: 23 February 2018

\begin{abstract}
Promoting recycled aggregates from construction and demolition (C\&D) waste for producing concrete will reduce the demand on conventional aggregates and it is an alternative to effectively manage C\&D waste. Application of recycled C\&D aggregates as a substitute to conventional aggregates in low strength concretes is the best way to initiate this in the industry. Therefore, this study focused on investigating the strength properties and the influence of time on the behaviour of strength gaining of concrete elements made by mixing the conventional aggregates and recycled C\&D aggregates. The grade of the concrete was 25 . The research methodology involved replacing the conventional coarse aggregates partially with $0 \%, 20 \%, 40 \%$ and $60 \%$ recycled C\&D aggregates in concrete mixtures. Test cubes were cast for each percentage of the materials and other conditions were kept as constants. The test cubes were then subjected to compressive strength test under three test series. The test series were focused on different curing periods of the specimens as 7,28 and 90 days to determine the behaviour of strength gaining with time. The conclusion drawn from the study is that it is feasible to substitute up to $40 \%$ of coarse aggregates by recycled C\&D aggregates in conventional low-intermediate strength concrete applications with the specified mix design.
\end{abstract}

Keywords: Compressive strength, construction and demolition, non-structural concrete.

\section{INTRODUCTION}

Construction and demolition waste (CDW) is one of the heaviest and most voluminous waste generated by the construction sector. Construction waste management is a crucial issue in which significant attention should be invested in order to control and manage it. Effectively managed CDW results in more benefits since it consists of numerous materials, many of which can be recycled and reused (Wu et al., 2016). Recycling CDW is only attractive when the recycled product is competitive with natural resources in relation to quality, cost and quantity (Hendriks \& Pietersen, 2000) and then the best option is to reuse the CDW as construction materials. The recycled construction and demolition (C\&D) aggregates could be a reliable alternative to replace natural aggregates in concrete construction. Currently the reuse of recycled materials extracted from CDW is growing all over the world and has demonstrated sufficient promise for using as a component in new concrete. However, it is not prevalent in many developing countries.

Use of materials from recycled C\&D waste in civil engineering applications as a construction material is a developing trend. Although recycled C\&D aggregates do not satisfy all the qualities when compared to conventional construction materials, it has shown potential use as an unbound pavement material (Jayakody et al., 2014; Gobieanandh \& Jayakody, 2016; Ossa et al., 2016). Detailed investigation on the performance characteristics of recycled aggregates extracted from C\&D waste as an unbound pavement material was recently conducted by Jiménez et al. (2012), Jayakody et al. (2013) and Arulrajah et al. (2013). The studies revealed significant results which were highly resistant on elastic and plastic

*Corresponding author (jshiran@gmail.com; (iD https://orcid.org/0000-0003-0077-3962)

This article is published under the Creative Commons CC-BY-ND License (http://creativecommons.org/licenses/by-nd/4.0/). This license permits use, distribution and reproduction, commercial and non-commercial, provided that the original work is properly cited and is not changed anyway. 
deformations against repetitive loading and it was further proved by the state-of-the-art study conducted by Cardoso et al. (2016).

The use of aggregates from recycled $C \& D$ waste in different types of concrete applications is not widely reported over the past decades but now shows an increase in some regions especially in developed countries. The uncertainty is raised to obtain the same properties of conventional concrete structures, with the use of recycled $C \& D$ aggregates due to the presence of various constituents (Hoffmann et al., 2012). According to the study of Özalp et al. (2016), the use of C\&D aggregates in the production of concrete should be done with proper separation and classification of their constituents. The appropriate ratio of C\&D aggregates should be lower to obtain the sufficient conditions of the concrete and it is suggested to be around $20 \%$ (Silva et al., 2014; Özalp et al., 2016). Silva et al. (2014) further suggested to produce a practical means of measuring the quality of recycled C\&D aggregates, to produce concrete with predictable performance.

The chemical properties of recycled $C \& D$ aggregates can vary widely depending on the source of parent materials from which they are derived (Padmini et al., 2009). Therefore, Martín-Morales et al. (2011) suggested with his study to evaluate the impact of sulphate and chloride content in C\&D aggregates prior to the applications in concrete productions. According to past studies, the engineering properties of the produced recycled $\mathrm{C} \& \mathrm{D}$ aggregates in a particular region should be investigated prior to their application since the characteristics are varied region to region (Tabsh et al., 2009) due to the quality and constituents in the parent materials.

This study was intended to identify the potential of reusing recycled $\mathrm{C} \& \mathrm{D}$ aggregates to manufacture nonstructural concrete in Sri Lanka. Non-structural concrete consists of low-intermediate strength and mostly used (López-Uceda et al., 2016) for concrete driveways, footing in non-aggressive environment, foundation trenching, pipe-beddings, levelling surfaces, subgrade for foundations and structural slabs, shoulders, median barriers, sidewalks, kerbs and for ornamental urban elements etc. Determination of the characteristics of recycled C\&D aggregates as a concrete metal should be done with comprehensive experimental data. Therefore, a detailed experimental programme was conducted to investigate the strength properties and strength development with time of the concrete, when the conventional aggregates in different fractions is replaced by recycled $\mathrm{C} \& \mathrm{D}$ aggregates.
The influence of recycled C\&D aggregates on the properties of non-structural concrete elements has not been widely studied in Sri Lanka. This study will suggest effective and efficient improvements to minimise the use of conventional aggregates in concrete industry by determining the strength characteristics of concrete made by recycled $C \& D$ aggregates.

Re-using and recycling C\&D waste contribute to sustainable use of construction material in industry and it is required to increase the awareness on feasible use of recycled $C \& D$ aggregates in construction industry. The production of aggregates from these wastes reduces the extraction of natural rocks and reduces the carbon emission of producing concrete aggregates (Ghosh \& Ghosh, 2016).

\section{METHODOLOGY}

\section{Materials}

The recycled materials for the research were acquired from a leading waste recycling plant named COWAM Centre in Galle, Sri Lanka. Commercially available recycled C\&D aggregates were obtained. Natural concrete aggregates were obtained from a crusher plant in Mirigama and river sand was from the same area in Western Province in Sri Lanka. These were commercial materials for industrial applications. Figure 1 shows the representative samples of recycled $C \& D$ and natural coarse aggregates used for the study.

\section{Experimental programme}

\section{Materials characterisation}

The natural coarse aggregates, sand and recycled C\&D aggregates were tested to characterise their properties to ascertain the suitability for producing concrete. Table 1 shows the results of the tests conducted and the material type with the standard test methods.

\section{Coarse aggregates mix ratios for samples}

The study focused on substituting the recycled C\&D aggregates for conventional concrete aggregate, to determine the appropriate boundary percentage of C\&D aggregates that can be added to manufacture non-structural concrete for target compressive strength. Natural coarse aggregates were replaced by recycled C\&D aggregates with different percentages by weight as shown in Table 2. 
Table 1: Tests and their standard methods for conventional concrete aggregates, sand and recycled C\&D aggregates

\begin{tabular}{lcccc}
\hline Test & \multicolumn{2}{c}{ Type of material } & Test method \\
\hline Sieve analysis test & Coarse & Sand & C\&D & BS 1377-part 2:1990 (British Standards Institution, 1990c) \\
Bulk density & Coarse & Sand & C\&D & BS 812-part 2 (British Standards Institution, 1995) \\
Aggregate impact value & Coarse & - & & BS 812-part 112:1990 (British Standards Institution, 1990b) \\
$\begin{array}{l}\text { Flakiness index } \\
\text { Clay and silt content }\end{array}$ & Coarse & - & & BS 812-sec.105.1:1989 (British Standards Institution, 1990a) \\
Specific gravity and water absorption & Coarse & & C\&D & BS 812 (British Standards Institution, 1989) \\
& & & BS 812-part 2 (British Standards Institution, 1995) \\
\hline
\end{tabular}

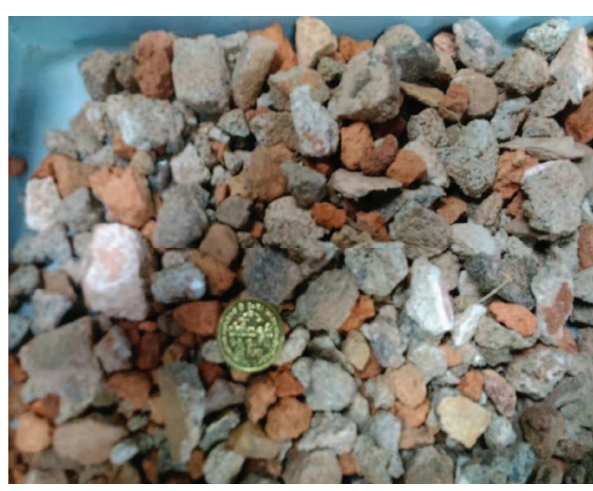

(a)

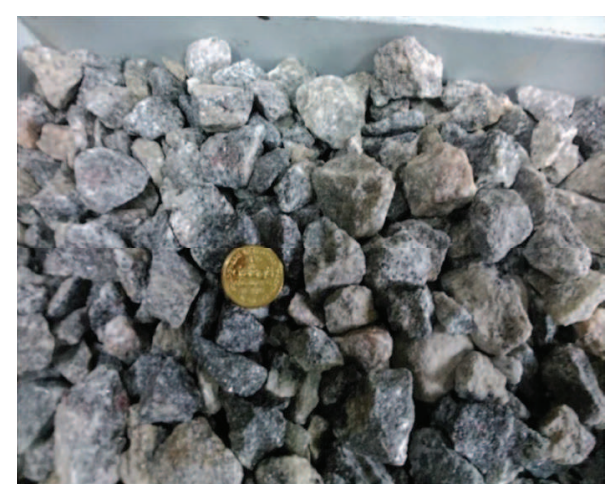

(b)

Figure 1: (a) Recycled construction and demolition aggregates; (b) natural aggregates

Table 2: Sample names with coarse aggregates mix ratios

\begin{tabular}{lcc}
\hline Sample name & $\begin{array}{c}\text { Natural aggregates } \\
\text { (\% by weight) }\end{array}$ & $\begin{array}{c}\text { C\&D aggregates } \\
\text { (\% by weight })\end{array}$ \\
\hline NA100/CD0 & 100 & 0 \\
NA80/CD20 & 80 & 20 \\
NA60/CD40 & 60 & 40 \\
NA40/CD60 & 40 & 60 \\
\hline
\end{tabular}

Table 3: Concrete mix design information for grade 25 concrete mixture

\begin{tabular}{ll}
\hline Component & Value \\
\hline Design strength & $25 \mathrm{Nmm}^{-2}$ in 28 days \\
Standard deviation & $8.0 \mathrm{Nmm}^{-2}$ \\
Margin & $1.64 \times 8.0=13.12 \mathrm{Nmm}^{-2}$ \\
Target mean strength & $25+13.12=38.12 \mathrm{Nmm}^{-2}$ \\
Free water/cement ratio & 0.535 \\
Slump & $110-130 \mathrm{~mm}$ \\
Maximum aggregate size & $20 \mathrm{~mm}$ \\
\hline
\end{tabular}

\section{Compressive strength test}

Compressive strength test for concrete cubes is of utmost importance, which reveals the strength and stiffness properties of the concrete. Test results are primarily used to determine whether the concrete mixture meets the requirement of a specified strength. The compressive strength test was conducted in accordance with BS EN 12390-2 (British Standards Institution, 2009). Tests were conducted under 3 series based on curing periods of the specimens prior to the tests. The curing periods were planned to examine the strength gaining of the concrete specimens with time.

Series I : Specimens cured for 7 days.

7 days curing period was selected to check strength properties before standard curing period which is 28 days and to investigate the performance under site curing.

Series II: Specimens cured for 28 days.

This is the control test for the curing time. Usually 28 days curing was done to follow the standard test procedure. 
Series III: Specimens cured for 90 days.

90 days curing was selected to investigate the strength gain which is beyond the standard curing time period of 28 days. This is to examine the effect of re-cementing process due to the hydration of residual cement in cement mortar which is attached to the recycled aggregates and conglomerated cement mortar particles in $\mathrm{C} \& \mathrm{D}$ samples.

\section{Concrete mix design}

The non-structural concrete elements generally refer to the grade of concrete less than $25 \mathrm{MPa}$ (Anum et al., 2014). This study was conducted to prepare Grade 25 concrete mixes for sample preparation, since lowintermediate strength concrete is widely used in nonstructural applications. Achieving the strength of $25 \mathrm{MPa}$ is essential to ensure the potential use of recycled C\&D for non-structural concrete applications.

Concrete mix design calculation was carried out according to the British (DOE) method (Teychenne, 1997). The strength requirements for concrete are taken at an age of 28 days as it is the standard curing time (British Standards Institution, 2009). A higher standard deviation was employed in order to determine the target mean strength based on the required design strength, when designing the concrete mixed with recycled C\&D aggregates of variable quality (Rao et al., 2007). All specimens were prepared as a standard mixture for Grade 25 mix-design as shown in Table 3.

According to the mix design information in Table 3, the calculated quantities of materials for $1 \mathrm{~m}^{3}$ of concrete is as follows

- Cement $370 \mathrm{~kg}$

- Water $180 \mathrm{~kg}$

- Sand $785 \mathrm{~kg}$

- Natural aggregate $(20 \mathrm{~mm}) 1080 \mathrm{~kg}$

The water content was initially calculated as $180 \mathrm{~kg}$ for a $1 \mathrm{~m}^{3}$ volume of the mixture. It was later modified as $198 \mathrm{~kg}$ to increase the workability of the concrete mixture.

Proportioning of concrete mixtures: The quantities of the materials for $1 \mathrm{~m}^{3}$ were adapted to produce the required volume of concrete specimens for testing. The required coarse aggregates were partially replaced by substitution of recycled $\mathrm{C} \& \mathrm{D}$ aggregates as the mixed proportions of coarse aggregates as shown in Table 2.
Mixing of components: The minor constituents in C\&D such as metal, wood pieces, plastic and paper were removed before mixing. These materials could be added at the crushing process and were removed in order to maintain the consistency of the selected sample. In addition, to compare the results objectively, NA100/CD0 sample was used as the control mix which was made from natural coarse aggregates to benchmark the results. All concrete mixes were prepared with the slump in the range of $110-130 \mathrm{~mm}$. These slump values were achieved by adding more water within the range of $5-10 \%$ than the designed values due to high water absorption property of C\&D aggregates (Deshpande et al., 2012).

The test cubes were manufactured according to the standard of BS EN 12390-2:2009 (British Standards Institution, 2009) and the size was $150 \mathrm{~mm} \times 150 \mathrm{~mm}$ $\times 150 \mathrm{~mm}$. The test cubes were covered with damp cloth and stored at room temperature for $24 \mathrm{~h}$ (British Standards Institution, 2009).

Testing the specimens: Concrete cubes were removed after $24 \mathrm{~h}$ and immersed in a water tank for curing where the water temperature was controlled at $20{ }^{\circ} \mathrm{C} \pm 2{ }^{\circ} \mathrm{C}$, allowing the cubes to hydrate properly under a moist environment. The cured test cubes were removed from the curing tank after the designed curing periods and tested for compressive strength under the test method BS EN 12390-2 (British Standards Institution, 2009). The compressive strength test machine and the tested samples are shown in Figure 2. The failure patterns of the tested samples were inspected to decide whether they were satisfactory.

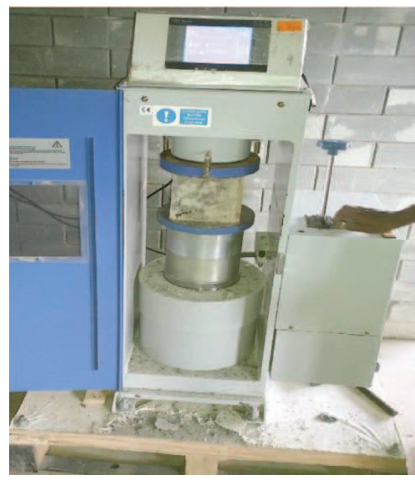

(a)

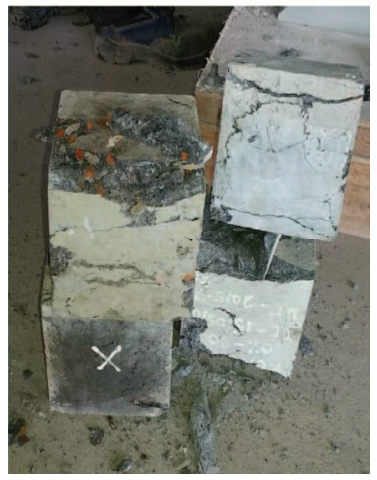

(b)
Figure 2: (a) Testing a concrete specimen; (b) tested concrete cubes 


\section{RESULTS AND DISCUSSION}

Physical properties of the used materials; natural coarse aggregates, sand materials and recycled C\&D aggregates were investigated prior to the main testing programme. The determination of basic physical properties is significant to compare with the standard specifications and to classify the materials. These records would be utilised for future comparison and recommendation, when these properties change with certain conditions in different regions.

\section{Properties of conventional coarse aggregates}

\section{Particle size distribution (PSD)}

The particle size distributions of natural coarse aggregates are graphically shown in Figure 3 with the upper and lower bounds of British specification BS 882-1992 (British Standards Institution, 1992). The grading curve was within the recommended grading limits for single sized aggregates and the gradation of the aggregates is desirable for making concrete, as it reduces

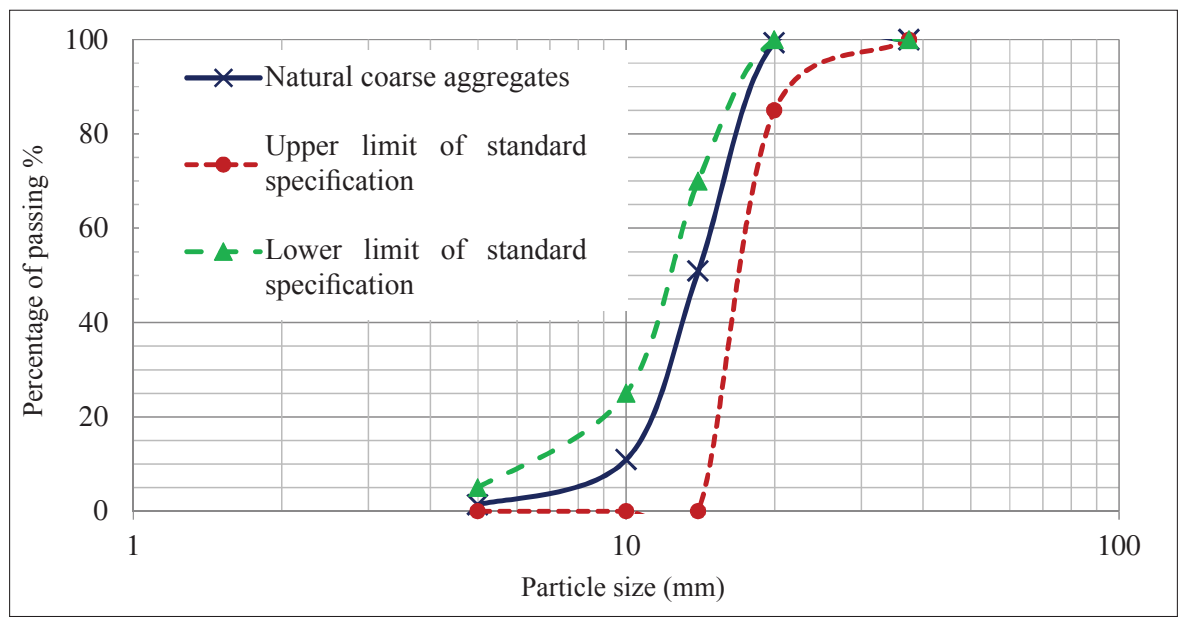

Figure 3: Grading curve of natural coarse aggregates with British Standard (BS 882) for single sized aggregates

the void content to produce a well-packed concrete mix (Smith \& Andres, 2011). According to the coefficients of uniformity and curvature values of the PSD curve, it is not perfectly well graded, however can be introduced as slightly well graded. The maximum particle size is $20 \mathrm{~mm}$, which is acceptable for the economic production of concrete with standard quality.

\section{Mechanical properties}

Aggregate impact value (AIV) was measured to evaluate the strength of the aggregates. AIV is the percentage of fines produced from the aggregate sample after subjecting to a standard impact load. It gives a relative measure of the toughness or the resistance of aggregate to a sudden impact such that cube shaped stones give higher resistance to impact when compared with flaky and elongated stones. The AIV test was carried out in accordance with BS 812-part 112 (British Standards Institution, 1990b). The required AIV should be less than $30 \%$ as defined in BS 882-1992 (British Standards Institution, 1992). The used natural aggregates have AIVs of $29.9 \%$ and $29.5 \%$, which is within the standard limit and suitable for use in concrete structures.

\section{Physical properties}

Specific gravity of the coarse aggregates was measured as 2.79 and the water absorption value was $0.20 \%$ at dry basis. Further, the flakiness index and bulk density of the natural coarse aggregates were measured. The value of bulk density clearly depends on grading, which governs how well the particles pack together when compacted. The bulk density of the natural coarse aggregates was $1422.5 \mathrm{kgm}^{-3}$, which is within the standard range 1200 to $1760 \mathrm{kgm}^{-3}$ (E-701, 1999). 


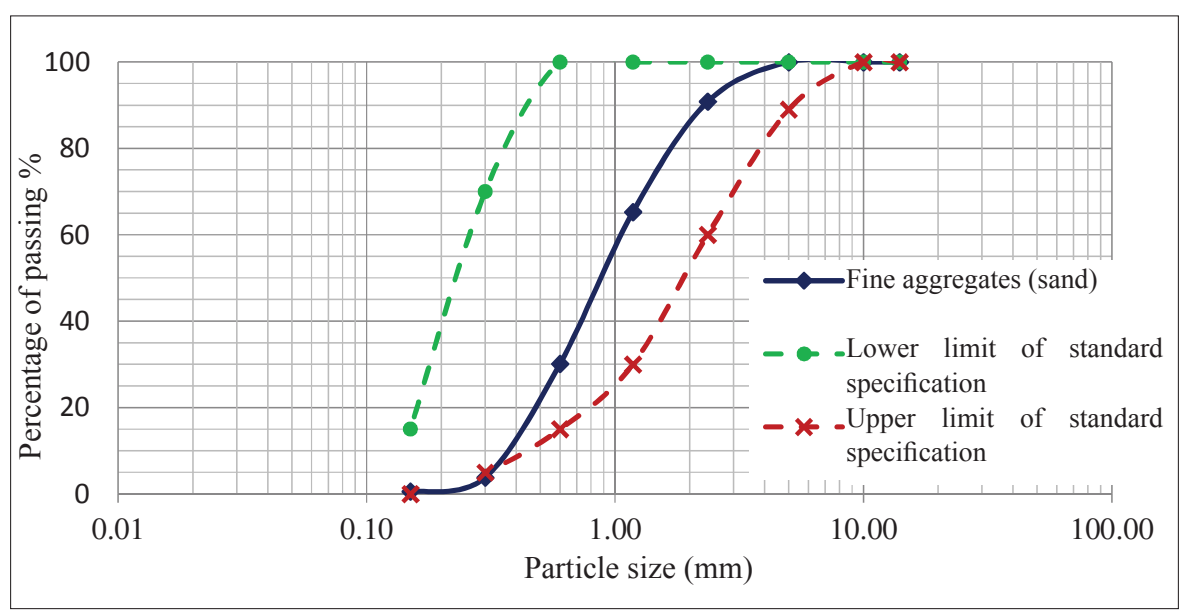

Figure 4: Grading curve of fine (sand) aggregates with British Standard (BS 882)

Flakiness index of the natural coarse materials was measured to determine the percentage by weight of flaky particles in the samples. The degree of packing of particles of one size depends upon their shape. Flaky particles reduce the workability of concrete mixes due to high surface area to volume ratio. When determined in accordance with BS 812-part 105 -1 (British Standards Institution, 1990a), the flakiness index should not exceed $40 \%$ for crushed rock (British Standards Institution, 1992). The obtained flakiness index value was $14 \%$; hence the selected conventional coarse material was acceptable.

\section{Properties of fine aggregates (sand)}

\section{Particle size distribution (PSD)}

PSD of the fine aggregate is graphically shown in Figure 4 with the British specification for upper and lower limit of standard PSD. The graph ensures that the PSD of natural fine aggregates complied with the upper and lower limits of grading, which were provided by British standard test specifications (British Standards Institution, 1992).

Bulk density of the sand materials was between $1476-1481 \mathrm{kgm}^{-3}$. The values were within the standard specifications $1200-1760 \mathrm{kgm}^{-3}(\mathrm{E}-701,1999)$ and were suitable for the concrete mixture.

\section{Clay and silt content of fine aggregates}

The aggregates for producing concrete should be clean of impurities (Ngugi et al., 2014). Therefore, it is significant to control the effect of clay and silt content of sand on the strength of the concrete. The higher the percentage of clay and silt in sand, the lower the concrete strength (Olanitori, 2006). The British standards (British Standards Institution, 1992) have imposed a limit on the maximum amount of finer material passing $75 \mu \mathrm{m}$ (No. 200) sieve in fine aggregate as $4 \%$. The determined clay and silt content value was $1.31 \%$, which was well below the maximum permissible margin.

\section{Properties of recycled $C \& D$ aggregates}

\section{Constituents and clay-silt content in $C \& D$}

The constituents of the recycled $\mathrm{C} \& \mathrm{D}$ aggregates were quantified at the beginning of the test programme, to be used for future reference. The quantification was conducted manually and the weighted averaged results are shown in Table 4. It can be seen that the major constituents of recycled $\mathrm{C} \& \mathrm{D}$ waste is recycled concrete aggregates and it is around $80 \%$ by weight.

Table 4: Constituents of recycled C\&D aggregates

\begin{tabular}{ll}
\hline Constituent & Average percentage by weight \\
\hline Recycled concrete aggregates & $<80-90 \%$ \\
Brick & $<15 \%$ \\
Ceramics, clay tiles and glass & $<5 \%$ \\
Wood and other debris & $<2 \%$ \\
\hline
\end{tabular}


The silt and clay content of the recycled C\&D aggregate samples is a critical factor, which adversely affects the strength of the concrete. The measured value of silt and clay content was $1.4 \%$ by weight in the C\&D aggregates. The main constituent of C\&D wastes such as cement mortar and bricks contribute to a high percentage of fine contents in recycled $\mathrm{C} \& \mathrm{D}$ aggregates.

\section{Particle size distribution (PSD) of C\&D}

The PSD of C\&D aggregates is graphically shown in Figure 5 with the upper and lower limit of British standard specifications (British Standards Institution, 1992) for concrete coarse aggregates.

The graph revealed that the C\&D aggregates are scattered up to $50 \mathrm{~mm}$ in size. From the shape of the PSD curve it can be concluded as well graded, which is suitable for producing good workable concrete. Comparison of the shape of curve with the recommended PSD limits, which are provided for natural coarse aggregates by BS test specifications reveal that approximately $15 \%$ of C\&D falls within coarse grading limits. Thus, it can be concluded that a major part of the particle size distribution curve obtained for C\&D does not comply with the standard range. Greater portion of the aggregates' size is higher than the standard limit and strengthens the concrete specimens. Bigger aggregates result in larger inter-facial transition zone, which increases the possibility of cracks occurring, and internal bleeding could take place due to the trapped water (Bjøntegaard et al., 2004). However, the results of strength properties of the different concrete specimens, which is discussed in the next section revealed that the strength was not adversely affected by the PSD of C\&D aggregates. Modification of the recycling crusher plant is suggested to get the aggregates within the standard specification. Using the recycled C\&D aggregates in concretes with standard grading limits can result in higher strength than the observed strength.

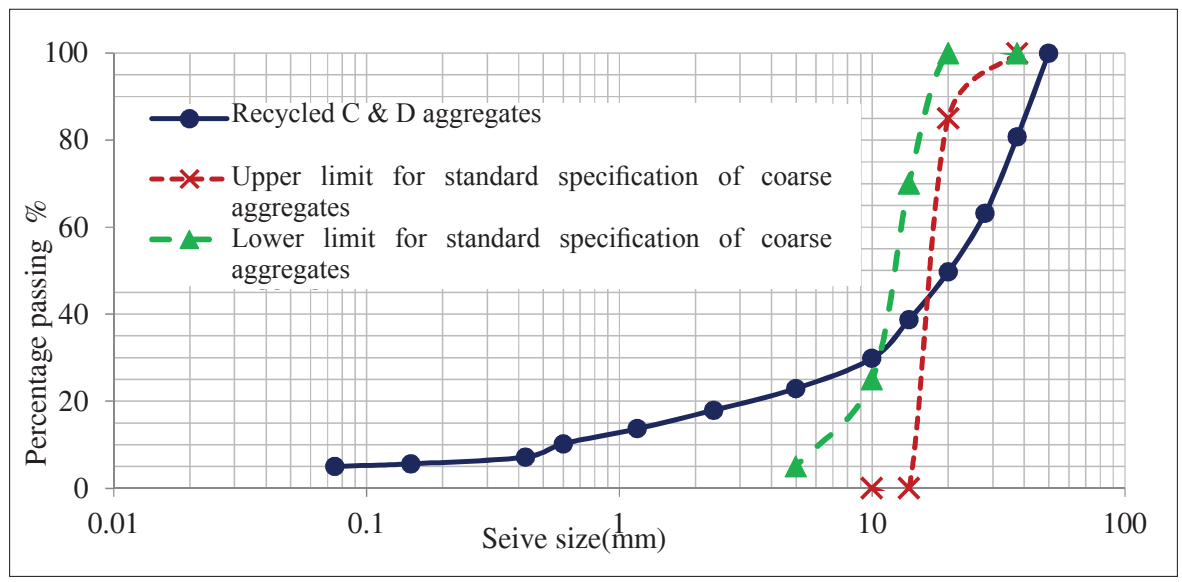

Figure 5: Grading curve of recycled C\&D aggregates with British standard (BS 882)

\section{Physical properties}

The bulk density of the recycled C\&D aggregates was $1348 \mathrm{kgm}^{-3}$ which is less than that of the natural coarse aggregates; however, it is within the standard range 1200 to $1760 \mathrm{kgm}^{-3}$ (E-701, 1999). Presence of constituents such as bricks and glass cause lower bulk density in C\&D than in natural aggregates. The specific gravity and water absorption properties were measured as 2.66 and $2.71 \%$, respectively. The presence of low dense constituents and high porosity in the attached cement mortar with the aggregates cause lower specific gravity than natural coarse aggregates (Manzi et al., 2013). Presence of finer and higher porosity in smaller sized recycled aggregates cause high water absorption (Jayakody et al., 2017). High water demanding property of C\&D aggregates generates adverse impact on the workability of concrete mixtures and strength gaining of concrete structures.

\section{Properties of concrete with C\&D}

\section{Workability of the fresh concrete}

Significant reduction in slump between the natural aggregate mixtures and C\&D mixtures was observed when the water: cement ratio was 0.49 . The concrete with 
recycled aggregates lost their workability immediately due to high absorption of water. Therefore, water content was modified for the concrete mixtures by following the findings of Deshpande et al. (2012) by adding $5-10 \%$ more water to achieve higher slump. Thus the modified cement: water ratio was 0.535 . The workability of the concrete mixture was increased with the modified water content and the resulting slump values of different concrete mixtures are shown in Table 5. However, use of high-performance super plasticiser is more time-effective in achieving the desired workability and strength (Matias et al., 2013) when varying the incorporation rate of recycled C\&D, which is not concerned in this study.

Recycled C\&D aggregates present a higher porosity and lower density than natural aggregates due to the old mortar coating attached to the aggregates and the presence of impurities such as brick particles (Bodin \& Zaharieva, 2002). This contributes to an increase in water and air flow into the aggregate resulting in higher water absorption. Then it was related to the increase in water percentage in the mix in order to preserve the workability. Further, the lower slump values in the C\&D concrete mixtures were due to the roughened surface texture and the more angular shape of the recycled aggregates, which enhanced the inter-particle friction in fresh concrete (Butler et al., 2011). However, the increase in water content affects strength properties. Higher strength can be expected than the obtained values with $C \& D$, if plasticising admixtures are used to increase the workability while maintaining the same amount of water in every fresh mix (Tabsh \& Abdelfatah, 2009).

The results of the study done by Mas et al. (2012) suggested to eliminate slump loss when using recycled aggregates in concrete by pre-saturating the aggregates before mixing. It has been suggested to pre-soak the recycled coarse aggregates by a sprinkler system for 24 hours prior to the application and to cover with a plastic sheet in order to maintain the humidity. A recommended level of humidity could be $80 \%$ of the total absorption capacity (Mas et al., 2012). Recycled C\&D aggregates were not soaked to be saturated in this study, as it would not probably result in an effective interfacial transition zone between the saturated recycled coarse aggregates and the new cement paste (Mas et al., 2012). Therefore, it is recommended to add water when the mixing process is in progress.

\section{Compressive strength of the specimens}

High inter-particle bonding strength between the coarse aggregate and the surrounding paste of the concrete made with recycled C\&D aggregate was expected (Tabsh $\&$ Abdelfatah, 2009) due to the angularity of the coarse aggregate and the residual cementation on the surface of the recycled aggregate. However, C\&D mixed concretes exhibit low compressive strength properties than the corresponding natural aggregate concrete. The decrease of the strength is proportional to the replacement ratio of natural aggregates. Four test cubes from each sample mix ratio (Table 2) were casted, cured and tested for different curing periods. The average values of compressive strength in each case have been shown with standard deviations in Table 5. The highest strength values are indicated as usual in the concrete with only conventional aggregates. The compressive strengths with substitution of C\&D aggregates up to $40 \%$ resulted in greater strength values than the design strength value $(25 \mathrm{MPa})$, after the standard curing time period of 28 days. Therefore, conventional concrete can be made with specified mix design for Grade 25 in low-intermediate strength concrete applications with the partial incorporation of C\&D up to $40 \%$. The substitution of about $60 \%$ of C\&D aggregates has given higher results than the target value of $25 \mathrm{MPa}$ only after 90 days, which indicates strength gaining beyond the standard value with time. Therefore, it can be recommended to use $60 \%$ of C\&D aggregates to replace conventional aggregates in non-structural concrete applications. The average compressive strength

Table 5: Averaged results for the compressive strength

\begin{tabular}{|c|c|c|c|c|c|c|c|}
\hline \multirow[t]{2}{*}{ Sample name } & \multicolumn{2}{|c|}{$\begin{array}{c}\text { Test series I } \\
\text { (7-days strength) }\end{array}$} & \multicolumn{2}{|c|}{$\begin{array}{c}\text { Test series II } \\
\text { (28-days strength) }\end{array}$} & \multicolumn{2}{|c|}{$\begin{array}{c}\text { Test series III } \\
\text { (90-days strength) }\end{array}$} & \multirow{2}{*}{$\begin{array}{l}\text { Slump } \\
\text { value } \\
(\mathrm{mm})\end{array}$} \\
\hline & $\begin{array}{c}\text { Compressive } \\
\text { strength }(\mathrm{MPa})\end{array}$ & $\begin{array}{l}\text { Standard } \\
\text { deviation }\end{array}$ & $\begin{array}{c}\text { Compressive } \\
\text { strength }(\mathrm{MPa})\end{array}$ & $\begin{array}{l}\text { Standard } \\
\text { deviation }\end{array}$ & $\begin{array}{c}\text { Compressive } \\
\text { strength (MPa) }\end{array}$ & $\begin{array}{l}\text { Standard } \\
\text { deviation }\end{array}$ & \\
\hline NA100/CD0 & 22.92 & 1.752 & 40.68 & 2.042 & 47.23 & 2.558 & 130 \\
\hline NA80/CD20 & 22.83 & 0.941 & 32.86 & 1.332 & 42.33 & 1.173 & 115 \\
\hline NA60/CD40 & 20.48 & 2.002 & 28.16 & 1.982 & 21.16 & 2.841 & 110 \\
\hline NA40/CD60 & 17.24 & 0.782 & 21.16 & 0.811 & 28.53 & 2.347 & 110 \\
\hline
\end{tabular}




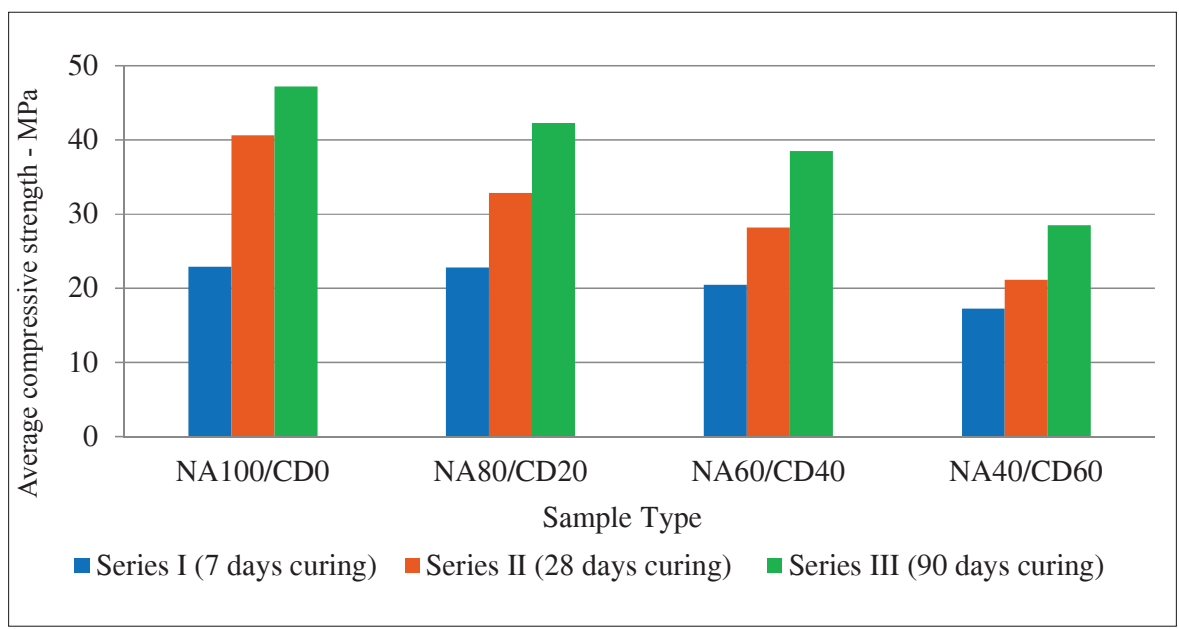

Figure 6: Strength variation of the concrete in terms of the C\&D percentage and curing periods

Table 6: Decrease of the strength with respect to the reference concrete with increasing C\&D

\begin{tabular}{lcccccc}
\hline Component & $\begin{array}{c}\text { 7-days } \\
\text { strength (MPa) }\end{array}$ & \% decrease & $\begin{array}{c}\text { 28-days } \\
\text { strength (MPa) }\end{array}$ & \% decrease & $\begin{array}{c}\text { 90-days } \\
\text { strength (MPa) }\end{array}$ & \% decrease \\
\hline NA100/CD0 & 22.92 & - & 40.69 & - & 47.23 & - \\
NA80/CD20 & 22.83 & 0.004 & 32.86 & 19 & 42.33 & 11 \\
NA60/CD40 & 20.48 & 11 & 28.16 & 31 & 38.53 & 18 \\
NA40/CD60 & 17.24 & 25 & 21.69 & 46 & 28.53 & 40 \\
\hline
\end{tabular}

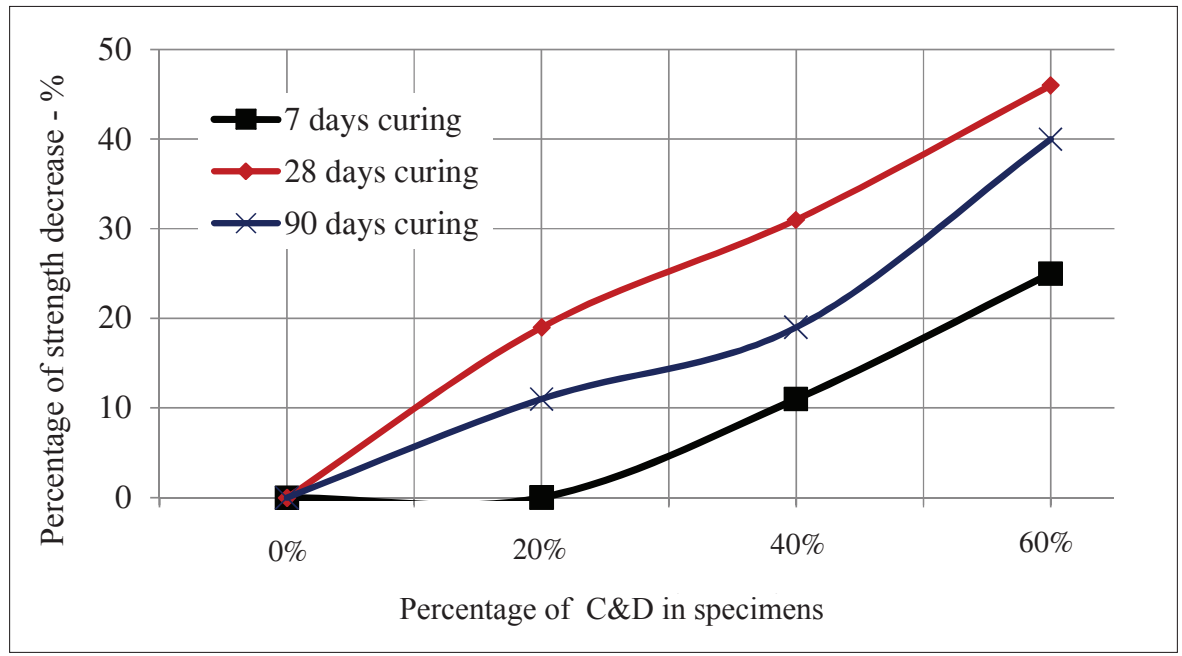

Figure 7: Percentages of strength decrease with increasing the recycled $C \& D$ aggregates with respect to the zero presence of $C \& D$ aggregates 
results in Table 5 is graphically represented in Figure 6. The compressive strength after 7 days curing time in conventional concrete and C\&D mixed concrete is quite similar. A slight decrease is observed for all substitutions. Therefore, the impact of C\&D for cementing process is negligible within 7 days curing. It indicates that the effect of C\&D on strength gaining does not significantly contribute during the early stage of concrete hardening.

Table 6 presents the percentage decrease of strength with increasing C\&D aggregates with respect to the concrete sample NA100/CD0, which was free of C\&D aggregates. These values are graphically shown in Figure 7 for the three different curing periods. A decrease in compressive strength with the increase of recycled C\&D aggregate proportion was observed due to the presence of constituents such as bricks, ceramics and wood etc. The percentage of decrease in strength with respect to the reference concrete NA100/CD0 increases as the C\&D portion increases at different ages of curing. These values of percentage of decrease, which are obtained in 28 days and 90 days are higher than that of 7 days. As for the NA40/CD60 specimen, the percentage decrease in 28 days and 90 days are $46 \%$ and $40 \%$, respectively. However, it is $25 \%$ in 7 days and indicates a significant lower value than 28 and 90 days. Furthermore, for the three samples which mixed C\&D aggregates, percentage decrease in the strength compared with the reference sample NA100/CD0 was less at 90 days than at 28 days. This reveals lowering the difference of gained strength of the specimens with time although the C\&D portion is increased.

As for the control sample NA100/CD0, values of 40.69 $\mathrm{MPa}$ and 47.23 $\mathrm{MPa}$ were observed respectively for 28 days strength and 90 days strength. However, in comparison to the specimen NA80/CD20 where it is related to the substitution of $20 \% \mathrm{C} \& \mathrm{D}$, the values 32.86 $\mathrm{MPa}$ and 42.33 $\mathrm{MPa}$ were observed respectively for the 28 days strength and 90 days strength. The significant difference in achieving strength even with substitution up to $20 \%$ of C\&D at different ages except for 7 days strength where the impact of the C\&D given for cementing process, is negligible.

Strength increment after 28 days is common for all the samples even when the percentage of C\&D increases. The possible reason for this is the presence of hardened conglomerated cement mortar particles and the old mortar coating attached to the aggregates. These need more curing time for hardening and re-cementation process with water absorption. When the quantity of old mortar in recycled C\&D aggregates increases, more time is taken for strength gaining. However, the reduction of loose and attached mortar that covers the aggregates significantly improves the contact surface between the new cement paste and the aggregate. It subsequently resulted in a significant improvement in the strength of concrete structures (Ismail et al., 2013).

Results of the study show the possible use of recycled C\&D aggregate in concretes and a promising solution to the problem of CDW management. It lowers environmental pollution and reduction of valuable landfill space. Greater efforts are required in the direction of creating awareness, especially in Sri Lanka, and relevant specifications are needed to establish the areas where the C\&D mixed concrete can be safely used.

\section{CONCLUSION}

The results obtained in this research lead to the following conclusions.

- High water absorption properties of recycled C\&D materials due to cement mortar and the presence of constituents such as bricks, roof tiles etc., demand more water for the concrete mixtures to maintain consistency in slump value.

- All the samples gained significant strength even after 7 days, which were greater than $20 \mathrm{MPa}$ except for the sample NA40/CD60. However, strength gaining does not significantly contribute during early stage of concrete hardening.

- The compressive strength increases with curing time even when the percentage of natural aggregates is decreased, while the percentage of recycled C\&D aggregates is increased.

- As the C\&D portion is increased, the percentage of decrease in strength with respect to the reference concrete (NA100/CD0) increases at different ages of curing. However, these percentage values are less at 90 days than at 28 days, which reveals increase of rate of strength gaining with time although the percentage of recycled C\&D aggregates is increased.

- The recycled C\&D aggregates can be used with the specified mix design for Grade 25 concrete, in low-intermediate strength concrete applications by replacing natural coarse aggregates up to $40 \%$.

- The sample NA40/CD60 does not show the required strength within 28 standard days of curing. However, it had the target strength at 90 days, which indicates the requirement of more time for continuous strength gaining when percentage of recycled C\&D aggregates is higher as compared to natural coarse aggregates. 


\section{Acknowledgement}

Authors express sincere gratitude to the Institution of Engineers, Sri Lanka for giving the invaluable and unique opportunity for this research project. Further the authors are grateful for the assistance given by ELS Pvt Ltd., Colombo who helped throughout the laboratory test programme.

\section{REFERENCES}

1. Anum I., Williams F.N., Adole A.M. \& Haruna A.C. (2014). Properties of different grades of concrete using mix design method. International Journal of Geology, Agriculture and Environmental Sciences (WOAR Journals) 2(6): 5.

2. Arulrajah A., Piratheepan J., Disfani M.M. \& Bo M.W. (2013). Geotechnical and geoenvironmental properties of recycled construction and demolition materials in pavement subbase applications. Journal of Materials in Civil Engineering 25(8): 1077 - 1088.

3. Bjøntegaard Ø., Hammer T.A. \& Sellevold E.J. (2004). On the measurement of free deformation of early age cement paste and concrete. Cement and Concrete Composites 26(5): $427-435$.

4. Bodin F.B. \& Zaharieva R.H. (2002). Influence of industrially produced recycled aggregates on flow properties of concrete. Materials and Structures 35(8): $504-509$.

DOI: https://doi.org/10.1007/BF02483138

5. British Standards Institution (1989). BS 812-103.2:1989 Testing aggregates. Method for determination of particle size distribution. Sedimentation test. British Standards Institution, Bristol, UK.

6. British Standards Institution (1990a). BS 812-105.1:1989 Testing aggregates. Methods for determination of particle shape. Flakiness index. British Standards Institution, Bristol, UK.

7. British Standards Institution (1990b). BS 812-112:1990 Testing aggregates. Method for determination of aggregate impact value (AIV). British Standards Institution, Bristol, UK.

8. British Standards Institution (1990c). BS 1377-2:1990 Methods of Test for Soils for Civil Engineering Purposes Part 2: Classification Tests. Determination of particle size distribution. British Standards Institution, Bristol, UK.

9. British Standards Institution (1992). BS 882:1992 Specification for aggregates from natural sources for concrete. British Standards Institution, Bristol, UK.

10. British Standards Institution (1995). BS 812-2:1995 Testing aggregates. Methods for determination of density. British Standards Institution, Bristol, UK.

11. British Standards Institution (2009). BS EN 12390-2:2009 Testing hardened concrete. Making and curing specimens for strength tests. British Standards Institution, Bristol, UK.

12. Butler L., West J.S. \& Tighe S.L. (2011). The effect of recycled concrete aggregate properties on the bond strength between RCA concrete and steel reinforcement. Cement and Concrete Research 41(10): 1037 - 1049.

DOI: https://doi.org/10.1016/j.cemconres.2011.06.004

13. Cardoso R., Silva R.V., de Brito J. \& Dhir R. (2016). Use of recycled aggregates from construction and demolition waste in geotechnical applications: a literature review. Waste Management 49: 131 - 145.

DOI: https://doi.org/10.1016/j.wasman.2015.12.021

14. Deshpande N.K., Kulkarni S.S. \& Pachpande H. (2012). Strength characteristics of concrete with recycled aggregates and artificial sand. International Journal of Engineering Research and Applications (IJERA) 2(5): 38 - 42.

15. E-701 D.b.C. (1999). ACI Education Bulletin E199 Aggregates for Concrete. Materials for concrete construction. American Concrete Institute.

16. Ghosh S. \& Ghosh S. (2016). Construction and demolition waste. Sustainable Solid Waste Management (pp. 511 547), American Society of Civil Engineers.

DOI: https://doi.org/10.1061/9780784414101.ch16

17. Gobieanandh V. \& Jayakody S. (2016). Evaluate the strength of cement treated recycled construction and demolition aggregates as a pavement material. $7^{\text {th }}$ International Conference on Sustainable Built Environment, Kandy, Sri Lanka 16 - 18 December, pp. $62-67$.

18. Hendriks C.F. \& Pietersen H.S. (2000). Sustainable raw materials-construction and demolition waste-State- of- theArt Report of RILEM TC 165-SRM (pp. 216).

19. Hoffmann C., Schubert S., Leemann A. \& Motavalli M. (2012). Recycled concrete and mixed rubble as aggregates: influence of variations in composition on the concrete properties and their use as structural material. Construction and Building Materials 35: 701 - 709.

DOI: https://doi.org/10.1016/j.conbuildmat.2011.10.007

20. Ismail S. \& Ramli M. (2013). Engineering properties of treated recycled concrete aggregate (RCA) for structural applications. Construction and Building Materials 44: 464 -476 .

DOI: https://doi.org/10.1016/j.conbuildmat.2013.03.014

21. Jayakody S., Gallage C. \& Kumar A. (2014). Assessment of recycled concrete aggregates as a pavement material. Geomechanics and Engineering, An International Journal 6(3): $235-248$.

DOI: https://doi.org/10.12989/gae.2014.6.3.235

22. Jayakody S., Gallage C. \& Ramanujam J. (2017). Effects of reclaimed asphalt materials on geotechnical characteristics of recycled concrete aggregates as a pavement material. Road Materials and Pavement Design 1 - 19.

DOI: https://doi.org/10.1080/14680629.2017.1417151

23. Jayakody S., Gallage C., Ramanujam J. \& Kumar A. (2013). Laboratory study on the performance of recycled concrete aggregates blended with reclaimed asphalt pavement as pavement granular material. Proceedings of the Third International Conference - Geomate 2013 Geotechnique, Construction, Materials and Environment, Nagoya, Japan 13 - 15 November, pp. $389-393$.

24. Jiménez J.R., Ayuso J., Agrela F., López M. \& Galvín A.P. (2012). Utilisation of unbound recycled aggregates from selected CDW in unpaved rural roads. Resources, Conservation and Recycling 58: 88 - 97. 
DOI: https://doi.org/10.1016/j.resconrec.2011.10.012

25. López-Uceda A., Ayuso J., López M., Jimenez J., Agrela F. \& Sierra M. (2016). Properties of non-structural concrete made with mixed recycled aggregates and low cement content. Materials 9(2): 74 .

DOI: https://doi.org/10.3390/ma9020074

26. Manzi S., Mazzotti C. \& Bignozzi M.C. (2013). Short and long-term behavior of structural concrete with recycled concrete aggregate. Cement and Concrete Composites 37(0): $312-318$.

DOI: https://doi.org/10.1016/j.cemconcomp.2013.01.003

27. Martín-Morales M., Zamorano M., Ruiz-Moyano A. \& Valverde-Espinosa I. (2011). Characterization of recycled aggregates construction and demolition waste for concrete production following the Spanish structural concrete code EHE-08. Construction and Building Materials 25(2): $742-748$.

DOI: https://doi.org/10.1016/j.conbuildmat.2010.07.012

28. Mas B., Cladera A., del Olmo T. \& Pitarch F. (2012). Influence of the amount of mixed recycled aggregates on the properties of concrete for non-structural use. Construction and Building Materials 27(1): $612-622$.

DOI: https://doi.org/10.1016/j.conbuildmat.2011.06.073

29. Matias D., de Brito J., Rosa A. \& Pedro D. (2013). Mechanical properties of concrete produced with recycled coarse aggregates - influence of the use of superplasticizers. Construction and Building Materials 44: 101 - 109. DOI: https://doi.org/10.1016/j.conbuildmat.2013.03.011

30. Ngugi H.N., Mutuku R.N. \& Gariy Z.A. (2014). Effects of sand quality on compressive strength of concrete: a case of Nairobi county and its environs, Kenya. Open Journal of Civil Engineering 04(03): 19. DOI: https://doi.org/10.4236/ojce.2014.43022

31. Olanitori L.M. (2006). Mitigating the effect of clay content of sand on concrete strength. $31^{\text {st }}$ Conference on Our World In Concrete and Structures, 16 - 17 August, Singapore.

32. Ossa A., García J.L. \& Botero E. (2016). Use of recycled construction and demolition waste (CDW) aggregates: a sustainable alternative for the pavement construction industry. Journal of Cleaner Production 135: 379 - 386. DOI: https://doi.org/10.1016/j.jclepro.2016.06.088

33. Özalp F., Yılmaz H.D., Kara M., Kaya Ö. \& Şahin A. (2016). Effects of recycled aggregates from construction and demolition wastes on mechanical and permeability properties of paving stone, kerb and concrete pipes. Construction and Building Materials 110: 17 - 23. DOI: https://doi.org/10.1016/j.conbuildmat.2016.01.030

34. Padmini A.K., Ramamurthy K. \& Mathews M.S. (2009). Influence of parent concrete on the properties of recycled aggregate concrete. Construction and Building Materials 23(2): $829-836$.

DOI: https://doi.org/10.1016/j.conbuildmat.2008.03.006

35. Rao A., Jha K.N. \& Misra S. (2007). Use of aggregates from recycled construction and demolition waste in concrete. Resources, Conservation and Recycling 50(1): 71 - 81. DOI: https://doi.org/10.1016/j.resconrec.2006.05.010

36. Silva R.V., de Brito J. \& Dhir R.K. (2014). Properties and composition of recycled aggregates from construction and demolition waste suitable for concrete production. Construction and Building Materials 65: 201 - 217. DOI: https://doi.org/10.1016/j.conbuildmat.2014.04.117

37. Smith R.C. \& Andres C.K. (2011). Materials of Construction. Gregg Division McGraw-Hill, New York, USA.

38. Tabsh S.W. \& Abdelfatah A.S. (2009). Influence of recycled concrete aggregates on strength properties of concrete. Construction and Building Materials 23(2): 1163 - 1167. DOI: https://doi.org/10.1016/j.conbuildmat.2008.06.007

39. Teychenne D.C. (1997). Design of Normal Concrete Mixes. BRE Bookshop, Garston, Watford, UK.

40. Wu Z., Yu A.T.W. \& Shen L. (2016). Investigating the determinants of contractor's construction and demolition waste management behavior in Mainland China. Waste Management 60: 290 - 300 . 